\title{
Discordant, non-syndromic, congenital diaphragmatic defects in sibs
}

\author{
TALAAT I FARAG*, MOHAMMED A ISSA †, AND \\ EL-SA YED MAHFOUZ† \\ ${ }^{*}$ Jahra Regional Liaison-Community Genetics Programme, and Kuwait Medical Genetics Centre, Maternity \\ Hospital; and †Pediatric Surgery Department, Ibn Sina Hospital, Kuwait.
}

\begin{abstract}
SUMmaRY We report an Arab sibship of two brothers with non-syndromic, congenital diaphragmatic defects (CDD). The first had an extensive, left, Bochdalek-type hernia and the second hemidiaphragmatic agenesis; these were verified by surgical exploration and necropsy respectively. The parents are healthy second cousins. Other reported discordant cases of CDD are briefly reviewed.
\end{abstract}

Congenital diaphragmatic defects have been classi-

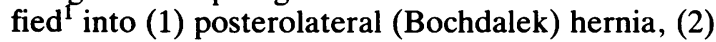
retrosternal (Morgagni) hernia, and (3) the rare extensive defects involving most or all of the hemidiaphragm (agenesis). They are generally considered to be one entity, that is, malformation or developmental defects with an incidence somewhere between 1 in 800 and 1 in $10000 .^{2-4}$ Makela $^{5}$ reported the first family with affected sibs in 1916 . Mertins, ${ }^{6}$ in 1952, was the first to suspect that CDD could occur in a familial aggregation. In Kuwait, we recently observed an Arab family with discordant, non-syndromic CDD in sibs.

\section{Case reports}

\section{CASE 1}

A male infant was born in 1984 after an uneventful, term pregnancy, weighing $3600 \mathrm{~g}$. He was the second child of phenotypically normal, second cousin Jordanian parents. At birth he looked normal. His Apgar scores were 8 and 9 at one and five minutes. He rapidly developed severe respiratory distress and metabolic acidosis. An extensive, left sided diaphragmatic hernia was diagnosed clinically and by chest radiography. The diagnosis was verified by surgical exploration. The hernial sac contained the stomach, the intestines extending to the splenic flexure, the spleen, the left lobe of the liver, and the left testis. It was repaired at the age of six hours. The baby died four hours later from cardiac arrest. The mother, when pregnant again, was given a low risk of recurrence on the basis of the multifactorial inheritance hypothesis.

CASE 2

This male sib of case 1 was born in 1985 at 38 weeks' gestation, weighing $2800 \mathrm{~g}$, after apparently normal ultrasonography findings in utero at 37 and 38 weeks. His Apgar scores were 1 and 3 at one and five minutes. He had progressive respiratory distress and acidosis, and he eventually died. Necropsy showed left hemidiaphragmatic aplasia. The left lobe of the liver, the spleen, the stomach, and most of the intestines were herniated into the thoracic cavity.

After two affected children, a high risk figure $(25 \%)$ was quoted to the parents. The mother had an early spontaneous abortion in 1986, a healthy daughter in 1988, and is now pregnant again, in her first trimester.

\section{Discussion}

The occurrence of discordant, non-syndromic CDD in sibs is well known. ${ }^{6-12}$ Most reported families had one baby with the Bochdalek type of hernia and the second with hemi- or bilateral diaphragmatic agenesis, indicating that both malformations may have common causes. In Arabs, Arad et al ${ }^{10}$ reported the first affected sibs in Jerusalem. In Kuwait, with a unique mosaic population, ${ }^{1314}$ we have to consider high recurrence - risk estimates, especially in CDD with extensive diaphragmatic defects or agenesis. ${ }^{15-20}$ The present family offers further evidence that among the frequent multifactorial cases of non-syndromic CDD are a few cases of autosomal recessive inheritance. ${ }^{15}$

\footnotetext{
References

1 Bingham JAW. Herniation through congenital diaphragmatic defects. Br J Surg 1959;47:1-15.

2 Andre JL. Affections diaphragmatiques du nouveau et de l'enfant

et leurs repeticussion sur la respiration. Thèse multi-office, Lausanne, 1971.

${ }^{3}$ David TJ, Parker VM, Illingworth CA. Diaphragmatic hernia in Avon. J Med Genet 1980;17:135.

4 Khawaja S, Al-Breiki H, Grant C, et al. Congenital diaphragmatic hernia. Saudi Med J 1984:5:229-35.
} 
${ }^{5}$ Makela V. Hernia diaphragmatica congenita sypuria Finska Lataresallskapet. Handlingar 1916;58:1107-27.

${ }^{6}$ Mertins $H$. Uber eine familiare Zwerchfellmi B bilding. Zentralbl Gynakol 1952;74:951-5.

7 Phillipp EE, Skeleton MO. Congenital diaphragmatic hernia in siblings. Br Med J 1952;i:1283-4.

8 Daentl D, Passarge E. Familial agenesis of diaphragm. Birth Defects 1972;8(2):24-6.

${ }^{9}$ Crane JP. Familial congenital diaphragmatic hernia: prenatal diagnostic approach and analysis of twelve families. Clin Genet 1979;16:244-52.

10 Arad I, Lijovetzky GC, Sorinsky R, et al. Diaphragmatic defects in children of consanguineous parents. Hum Genet 1980;55: 275-7.

"Gencik A, Moser H, Gencikova A, et al. Familial occurrence of congenital diaphragmatic defects in three families. Helv Paediatr Acta 1982;37:289-93.

12 Schubert-Staudacher E, Jauch $\mathrm{H}$. Two sibs with diaphragmatic defect. Clin Genet 1984;26:485-7.

13 National Census. Ministry of Planning, Kuwait, 1985.
14 Farag TI, Al-Awadi SA. Strategies in regional liaison and community genetic services in developing communities: a lesson from the Amish. Clin Genet 1988;34(6):395.

15 McKusick VA. Mendelian inheritance in man. 8th ed. Baltimore: Johns Hopkins University Press, 1988.

${ }^{16}$ Norio R, Kaariainen H, Roeala J, et al. Familial congenital diaphragmatic defects: aspects of etiology, prenatal diagnosis and treatment. Am J Med Genet 1984;17:471-83.

17 Wolff G. Familial congenital diaphragmatic defect: review and conclusions. Hum Genet 1980;54:1-5.

${ }^{18}$ Passarge E, Halsey H, German J. Unilateral agenesis of the diaphragm. Humgenetik 1968;5:226-30.

19 Ten Kate LP, Anders GTPA. Unilateral agenesis of the diaphragm. Humgenetik 1970;8:366-70.

20 Thomas MP, Stern LM, Moriss LL. Bilateral congenital diaphragmatic defects in two siblings. $J$ Pediatr Surg 1976;11: 465-7.

Correspondence to Dr T I Farag, PO Box 31145, Sulibikhat 90802, Kuwait.

\section{Porencephalic cyst in pycnodysostosis}

\section{J FIGUEIREDO*, A REIS*, R VAZ*, M LEÃO*†, AND C CRUZ*}

${ }^{*}$ Department of Neurology and Neurosurgery, Hospital de S Joäo; and †Department of Medical Genetics, Faculty of Medicine, Porto, Portugal.

SUMmARY We describe a case of pycnodysostosis with porencephaly and suggest an explanation for the porencephaly by a mechanism of imbalance between brain growth and its vascular supply and a normal but unopposed cerebrospinal fluid pressure.

Received for publication 25 January 1989

Revised version accepted for publication 25 May 1989
In 1962 Maroteaux and Lamy ${ }^{1}$ described a skeletal dysplasia the main features of which are generalised osteosclerosis and moderate dwarfism. They named? it pycnodysostosis meaning 'thick bones'.

Other features of pycnodysostosis include underdevelopment of the cranial sinuses; wormian bones; delayed closure of the fontanelles with wide, unossified cranial sutures; a beaked nose; a high, grooved palate; multiple dental abnormalities; hypoplastic
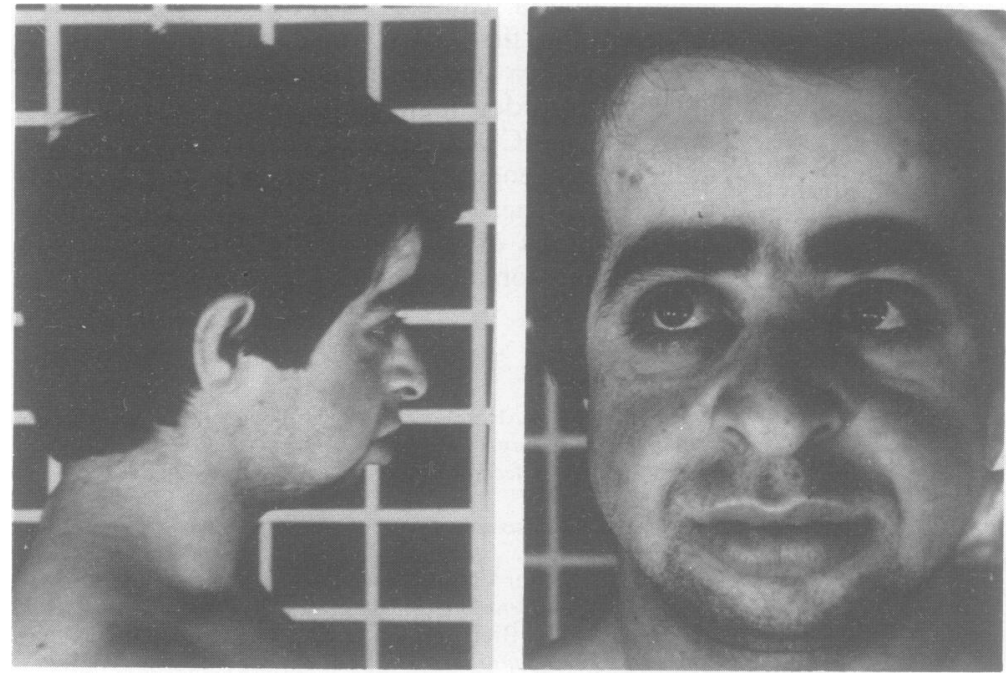

FIG 1 Proband's face with frontal bossing, large beaked nose, and small mandible. 